\title{
Classical Music as an Instrument to Foster Leadership Skills for Social Change: The Case of Venezuela's El Sistema
}

\author{
Marco Aponte Moreno \\ Saint Mary's College of California \\ Lance Lattig \\ Saint Mary's College of California
}

\begin{abstract}
El Sistema, the Venezuelan system of youth orchestras, is a program aimed at teaching and performing classical music through the development of a free network of symphony orchestras and choruses nationwide. Since its creation in 1975 by its founder José Antonio Abreu, El Sistema has given thousands of Venezuelan children, who often come from unprivileged socioeconomic backgrounds, the opportunity to receive free classical music education while promoting their personal, intellectual, spiritual, social, and professional development. The purpose of this article is to analyze El Sistema's potential to foster leadership skills for social change. After providing an overview of the program, we will apply Astin \& Astin's social change model of leadership development to shed light on El Sistema's capacity to foster leadership skills for social change among its young musicians.
\end{abstract}

Keywords: El Sistema, classical music, leadership skills for social change, social change model of leadership development, Venezuela

\section{Introduction}

One of the most iconic images of the Venezuelan antigovernment protests of 2017 was that of 23year-old violinist, Wuilly Arteaga, playing the national anthem as teargas canisters thrown by security forces exploded around him during a demonstration in Caracas (Saldivia, 2017). Armed with only his violin, the young musician became a symbol of peaceful protesters facing the brutal repression of Venezuela's authoritarian government (Sánchez, 2017).

Arteaga is not the only young musician who has reached prominence during the 2017 protests. In early May, Armando Cañizales, a 17-year-old violinist, was shot dead while participating in an antigovernment protest in Caracas. In addition to sharing ideals and dreams for a better future in their country, both musicians also shared the same musical education: they were trained in Venezuela's El Sistema, the world-famous network of youth orchestras. Cañizales was an active member when he died (Mora, 2017), while Arteaga had left the program after 2 years but continued training on his own (Sánchez, 2017).

El Sistema is a youth program aimed at teaching and performing classical music through the development of a free network of symphony orchestras and choruses nationwide (Kenyon, 2015). Since its creation in 1975, El Sistema has given thousands of Venezuelan children from lower and middle socioeconomic backgrounds free classical music education while fostering their personal, intellectual, spiritual, social, and professional development (Booth, 2015). 
El Sistema has received wide international recognition both for its capacity to produce social change (Rodas, 2006) and for the high artistic quality of its young musicians (Walkin, 2012). Thus, in addition to having exported its social and education model to over 40 countries, the Venezuelan system has successfully placed musicians in the world's leading orchestras. These include Edicson Ruiz, who at 17 became the youngest member of the Berlin Philharmonic, and Gustavo Dudamel, who is currently the director of the Los Angeles Philharmonic (Sánchez, 2007) and who has become a role model for El Sistema's younger musicians.

Is there anything in El Sistema's training that has contributed to nurturing the deep social consciousness and leadership spirit of Wuilly Arteaga, the symbol of peace for so many young protesters in Venezuela? Did El Sistema's values and beliefs play a role in Armando Cañizale's decision to raise his voice against a repressive government while losing his life for the sake of his country? Did El Sistema enable Gustavo Dudamel to develop the leadership qualities that allowed him to become such an important inspiration to so many younger musicians?

To understand how El Sistema works more broadly, we have conducted a review of articles and books written on the program. Although we have found a gap in academic publications covering $E l$ Sistema, we found that the program has inspired multiple authors to write press articles and books on a wide range of artistic, pedagogical, economic, and political aspects related to El Sistema. In this essay, we will start by providing an overview of the program while focusing on one of its most important characteristics: its capacity to produce social change. Then, we will analyze El Sistema's ability empower young children, who often come from unprivileged socioeconomic backgrounds, while nurturing in them individual, group, and community values, which are essential to their development as future leaders for social change.

\section{El Sistema: An Overview}

Venezuela has been producing classical musicians of international stature since the 19th century. One of the most prominent Venezuelan musicians was pianist and composer Teresa Carreño, who received international acclaim for her talent and virtuosity until her death in 1917. However, by the mid-1970s, Venezuela's main symphony orchestras were dominated by foreign musicians. It was in this context that José Antonio Abreu, an economist and musician, established his music program in 1975. With only 11 students, and working from a garage in the capital Caracas, he created his first orchestra. For Abreu, a key aim was to provide younger generations of Venezuelans with classical music education, through a combination of teaching and performance (Caselli, 2013).

After Abreu's orchestra won an international competition in Scotland, the Venezuelan government began to provide full funding for his program in 1979. El Sistema is funded by the Ministry of Social Services (previously called the Ministry of Youth), rather than the Ministry of Culture (Lubow, 2007). This social-welfare aspect reflects and reinforces El Sistema's aim to promote the social development of young people through classical music education and performance.

Originally known as Acción Social por la Música (Social Action for Music), El Sistema functions as a program of music for social action. With Venezuelan government support, Abreu's system of núcleos and módulos-or music education centers-has spread throughout the country. Today, an estimated 623,000 young Venezuelans participate in the program (El Sistema USA, 2017).

El Sistema serves all Venezuelans regardless of social class. Because centers are found in every part of the country, participants in El Sistema are not exclusively from disadvantaged families. Nonetheless, given Venezuela's widespread poverty and El Sistema's social-welfare mandate, most of 
the children are poor. In his book The Miracle of Music, Chefi Borzacchini (2010) presented a study showing that out of a sample of 180 families from 15 centers throughout Venezuela, $53 \%$ came from extreme poverty, $36 \%$ came from poverty, and only $11 \%$ came from middle class.

El Sistema's motto, "Tocar y luchar" ("To play and to struggle"), reflects the movement's musical and social aims. Music education and performance are central to El Sistema, but Abreu said he realized early on that the program had to do more than just play music. For him, the social and cultural benefits of being in an orchestra are as important as the artistic ones (Booth, 2015). In this sense, $E l$ Sistema's innovative practices of musical education go hand in hand with promoting social action.

Children in Venezuela join El Sistema by joining a núcleo. Early instruction focuses on rhythm and body movement and then progresses to recorders and percussion. At age 7, children choose a wind or string instrument and play for years before learning notation. Children learn through individual lessons, section work (small groups), and ensemble practice. At all three levels, the same teacher oversees a child's progress. Most of the teachers studied in El Sistema themselves, and they work closely with parents to foster their students' success. All instruction and instruments are free of charge (El Sistema USA, 2017).

Instead of focusing on countless hours of solitary practice, music instruction in El Sistema is resolutely social in nature. For the students, the immersion in ensemble work builds social cohesion from early childhood. Learning by performing is another key element; students frequently have the chance to perform in front of audiences, which fosters their communities' involvement in the program. Moreover, children learn by attending performances together and having lessons with prominent visiting musicians, such as Berlin Philharmonic conductor Simon Rattle (Booth, 2015).

Even though the term Sistema has become a byword for a specific method of musical education, particularly for Sistema-inspired programs in other countries, in Venezuela this name reflects a specific institutional framework. The "system" refers to the country's National System of Youth and Children's Orchestras and Choruses, which comprises approximately 200 youth orchestras and an estimated 60 children's orchestras (Schoenbaum, 2012). Although a few participants progress through the tiers of the system to play in the internationally recognized Simon Bolivar Youth Orchestra, thousands more students help realize Abreu's social and educational vision by performing for their local communities and teaching the next generation of young musicians (Booth, 2015).

\section{El Sistema's Capacity to Develop Leadership Skills for Social Change}

When Jamie Bernstein, Leonard Bernstein's daughter, saw for the first time the Simón Bolívar Youth Orchestra performing her father's "Mambo" from West Side Story, she thought the performance corresponded exactly to what her father really meant with his piece. According to Tricia Tunstall, a friend of Bernstein's and author of the book Changing Lives (Tunstall, 2012), Jamie Bernstein was talking about the combination of musical mastery and passionate communication between musicians and the audience (Johnson, 2012). It is this combination that gives audiences a feeling of exhilaration, leaving them with the impression of having been transformed by the experience.

The real transformation in El Sistema, however, occurs among its young musicians. The program literally changes their lives, giving them hope and purpose, a place in society. It provides them with a sense of belonging. It inspires them to work hard and excel at what they do. We argue that this transformational element allows El Sistema's young musicians to acquire essential leadership skills to foster social change in their communities. 
In order to analyze El Sistema's potential to promote leadership skills for social change, we have applied the social change model of leadership development. This model, developed by a team of researchers in the 1990s, led by Helen and Alexander Astin from University of California, Los Angeles, was originally intended to provide a framework for curriculum development in undergraduate leadership education programs in the United States (Astin \& Astin, 1996). However, the model is often used as an approach to leadership (the social change perspective). It conceptualizes leadership as a purposeful, collaborative and value-based process that results in social change. According to the model, there are seven critical values to leadership development. These values, which are often called the seven Cs (i.e., consciousness of self, congruence, commitment, collaboration, common purpose, controversy with civility, and citizenship), are classified into three categories: individual values, group values, and community values.

This model provides an excellent framework to assess El Sistema's potential to foster leadership skills considering the program's capacity to transform lives and produce social change. Moreover, the model's three perspectives to leadership (individual, group and society) fit well with the three learning approaches used in El Sistema (individual lessons, section work, and ensemble practices). Below, we will examine how El Sistema develops leadership skills for social change among its participants by analyzing the program's capacity to foster each of the seven Cs.

\section{Individual Values}

Individual values include the first three $\mathrm{Cs}$ in the model: consciousness of self, congruence, and commitment. Consciousness of self involves a strong awareness of one's own values, beliefs, attitudes and emotions. In the case of El Sistema, the quality of knowing oneself is directly related to the music performance element in the program. Like in any other performing art, music requires artists to know themselves and their own emotions well in order to deliver honest and truthful performances. If the performance is not authentic (reflecting the true self and emotion of the artist), it is unlikely to move the audience. Artists need to have a very strong sense of who they are and what they feel to be able to transmit emotional power, which is at the core of art.

A good example of this can be found in Gustavo Dudamel's work with the Youth Orchestra of Los Angeles. As he trains the children, he evokes characters and plots within the music, allowing the young musicians to make strong personal, emotional, and physical connections with the material (Booth, 2015). This technique is similar to what actors do when they approach a character. In their quest to find out who their characters are, they compare themselves to the characters, and ask themselves in which ways their characters are like them and in which ways they are different from them. This requires a strong knowledge of oneself (Hagen, 1991).

The second C, congruence, refers to the ability to behave in accordance with one's own principles and beliefs. That is to say, it deals with the capacity of being authentic. El Sistema triggers congruence at two levels: in the training and in performance.

In the training, students are always expected to behave with discipline, respect and compassion, which are fundamental values of the program. In this respect, José Hernandez-Estrada (2017), a Mexican American musician who has worked extensively with El Sistema, noted,

It is clear that El Sistema lives within a space of actionable compassion and transferable servant leadership. Giving young people an opportunity to lead is part of the secret to success. It also motivates them to grow and thrive both as musicians and citizens. (para. 8) 
When it comes to performances, students in El Sistema are not only expected to know themselves well and understand their own emotions, but they also have to be able to express them truthfully and authentically so that they can move audiences. Congruence between what one feels and the way one behaves in performance is a fundamental element in El Sistema, whose young musicians have often been praised for their capacity to convey true emotions in their concerts (Johnson, 2012).

Commitment, the third C, deals with having a significant investment to an idea or a person. It is a value that originates from within, but one that needs to be nurtured by the environment. In the case of El Sistema, this value is evidenced by the remarkable commitment that children have toward the instruments they play, the music they make, and the performances they give.

This commitment is reinforced by the active role that parents play in their children's music education. Infants who joined the system at 2 or 3 years of age receive various home visits to make sure parents understand the commitment that represents studying in El Sistema. Also, parents receive training and advice on how to manage their children's practice time at home, as well as on the importance of feedback and encouragement. When a student gets into an orchestra, they receive a stipend. This helps create a sense of value within the family for the child's artistic work. Also, considering the high levels of poverty that exist in Venezuela, the stipend becomes a necessary income for the subsistence of the family. This strengthens the commitment of the children and their parents toward El Sistema (El Sistema USA, 2017).

\section{Group Values}

Group values, the second set of values in the social change model, also includes three Cs: collaboration, common purpose, and controversy with civility. Collaboration involves working with others in a common effort, sharing responsibility and authority. Given that in an orchestra musicians need to play off each other, collaboration and mutual awareness are essential elements in rehearsals and performances.

Although each member of the orchestra plays an individual instrument, the ultimate goal is to excel as an ensemble. Sometimes musicians play together, while other times they perform solos. In $E l$ Sistema, collaboration is at the core of the training, not only because it involves being in an orchestra, but also because the training prioritizes group rehearsals over individual practices (Booth, 2015).

Common purpose, the second group value, deals with building a group's vision through shared aims and principles. In El Sistema, the role of its founder and artistic director, José Antonio Abreu, is key in developing this common purpose.

Alvaro Rodas (2006) identified the program's cohesive mission as well as Abreu's strong leadership for change and empowerment as the most important element in El Sistema's success. Similarly, Freddy Sánchez (2007) argued that Abreu's passion and commitment, coupled with his credibility as a music teacher, have allowed Abreu to share his vision with thousands of children who feel inspired to participate in the program. They become very engaged in both the social and artistic mission of the program (Booth, 2015).

Controversy with civility, the third group value, deals with the capacity to acknowledge that differences of opinion are unavoidable and that those differences should be discussed openly but with civility. Although El Sistema does not really provide many opportunities for students to question the music training they receive, they are encouraged to be tolerant in their dealings with other members. 
Teachers emphasize collegiality, mutual understanding and respect as key elements in the group creative process (Booth, 2015).

\section{Community Values}

In terms of community values, the social change model stresses the importance of citizenship (the seventh and final C). This deals with the capacity to believe in a process in which an individual or group becomes responsibly connected to society and the community through a shared activity.

As a social change and youth development program, El Sistema uses ensemble music to give every child the opportunity to be an asset within the community and society. The program not only develops musicians, but especially responsible citizens. This social mission is summarized in the slogan "To play and to struggle" (Booth, 2015).

In addition, $E l$ Sistema stresses building community as its main objective. As expressed by $E l$ Sistema's founder José Antonio Abreu (2009) in a Ted Talk, the development of children and their future roles in society are given more importance than music performance alone, which is essentially used as a tool for social change. A sense of belonging to a community and being valued by its members is achieved by fostering ensemble learning and triggering the search for excellence, both as musicians and human beings.

\section{Conclusion}

In this article, we have argued that El Sistema has the capacity to promote leadership skills for social change among its participants. As seen in our application of the social change model of leadership development, the program develops future leaders by nurturing individual, group, and community values, which are at the heart of social change. These values include self-awareness, authenticity, commitment, collaboration, common purpose, tolerance, and citizenship. Being a member of El Sistema is a source of pride for the children and their families, who often come from deprived socioeconomic backgrounds. Through the intense music training and the promotion of shared values, they become talented musicians, better human beings, and future outstanding leaders for their communities.

\section{References}

Abreu, J. A. (2009). The El Sistema music revolution [Video file]. Retrieved from https://www.ted.com/talks/jose_abreu_on_kids_transformed_by_music?language=en\#t-586465

Astin, H., \& Astin, A. (1996). A social change model of leadership development (Guidebook Version III). Los Angeles, CA: The National Clearinghouse of Leadership Programs.

Booth, E. (2015). What is El Sistema? The fundamentals that comprise the Venezuelan beacon. In C. Witkowski (Ed.), El Sistema: Music for social change (pp. 25-39). London, United Kingdom: Omnibus Press.

Borzacchini, C. (2010). The miracle of music. Caracas, Venezuela: Fundación Bancaribe. Retrieved from https://www.learner.org/workshops/k5music/uploads/venezuela-miracle-of-music.pdf

Caselli, I. (2013, December 4). José Antonio Abreu, Venezuela's musical visionary. BBC. Retrieved from http://www.bbc.co.uk/news/world-latin-america-25201492

El Sistema USA. (2017). El Sistema in Venezuela. Retrieved from https://www.elsistemausa.org/elsistema-in-venezuela.htm 
Hagen, U. (1991). A challenge for the actor. New York, NY: Scribner.

Hernandez-Estrada, J. L. (2017). El Sistema diary: Servant leadership [Blog post]. Retrieved from http://www.joseherstrada.com/blog/blog/el-sistema-diary-servant-leadership

Johnson, R. (2012, February 1). Tricia Tunstall on "changing lives" and a transformative Sistema. Los Angeles Times. Retrieved from http://articles.latimes.com/2012/feb/01/entertainment/la-et-triciatunstall-book-20120201

Kenyon, N. (2015). The triumph of a musical adventure. The New York Review of Books. Retrieved from http://www.nybooks.com/articles/archives/2015/sep/24/venezuela-triumph-musical-adventure/

Lubow, A. (2007, October 28). Conductor of the people. The New York Times. Retrieved from http://www.nytimes.com/2007/10/28/magazine/28dudamel-t.html?_r=0

Mora, F. (2017, May 4). Sistema de Orquestas lamentó muerte de Armando Cañizale [System of Orchestras regretted death of Armando Cañizales]. El Universal. Retrieved from $\mathrm{http} / / / \mathrm{www}$. eluniversal.com/noticias/entretenimiento/sistema-orquestas-lamento-muerte-armandocanizales_651216

Rodas, A. (2006). A model for community participation in the performing arts: Social action through music and the internationalization of the Venezuela orchestra system (Master's thesis). New York, NY: Columbia University Teachers College.

Saldivia, G. (2017, May 15). Tear gas doesn't stop Venezuelan protester from playing the violin. NPR. Retrieved from http://www.npr.org/2017/05/12/528072958/tear-gas-doesnt-stopvenezuelan-protester-from-playing-the-violin

Sánchez, F. (2007). El Sistema Nacional para las Orquestas Juveniles e Infantiles: La nueva educación musical de Venezuela [National System for Youth Orchestras: The new Venezuelan musical education]. Revista da ABEM, 18, 63-69.

Sánchez, F. (2017, June 7). Amid tear gas, Venezuela violinist symbolizes hope for peace. The Globe and Mail. Retrieved from https://www.theglobeandmail.com/news/world/amid-tear-gasvenezuela-violinist-symbolizes-hope-forpeace/article35231611/

Schoenbaum, D. (2012, November 30). Venezuela's El Sistema movement: Orchestrating a musical role model for the world. The Washington Post. Retrieved from https://www.washingtonpost.com/lifestyle/style/venezuelas-el-sistema-movement-orchestrating-a-musicalrole-model-for-the-world/2012/11/29/d0177258-37d7-11e2-b01f-5f55b193f58f_story.html

Tunstall, T. (2012). Changing lives: Gustavo Dudamel, El Sistema, and the transformative power of music. New York, NY: W. W. Norton \& Company.

Walkin, D. (2012). Fighting poverty armed with violins. The New York Times. Retrieved from http://www.nytimes.com/2012/02/16/arts/music/el-sistema-venezuelas-plan-to-help-children-throughmusic.html?_r=0

The Journal of Social Change, sponsored by Walden University, welcomes manuscripts focusing on interdisciplinary research in social change that improves the human condition and moves people, groups, organizations, cultures, and society toward a more positive future.

Walden University Publishing: http://www.publishing.waldenu.edu 